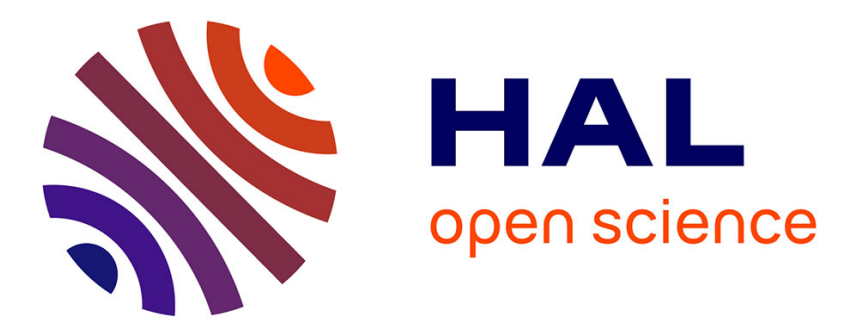

\title{
Myxoid epithelioid sarcoma: a diagnostic challenge! A report on six cases
}

Uta Flucke, Theo Jm Hulsebos, Han van Krieken, Thomas Mentzel

\section{To cite this version:}

Uta Flucke, Theo Jm Hulsebos, Han van Krieken, Thomas Mentzel. Myxoid epithelioid sarcoma: a diagnostic challenge! A report on six cases. Histopathology, 2010, 57 (5), pp.753. 10.1111/j.13652559.2010.03688.x . hal-00593450

\section{HAL Id: hal-00593450 https://hal.science/hal-00593450}

Submitted on 16 May 2011

HAL is a multi-disciplinary open access archive for the deposit and dissemination of scientific research documents, whether they are published or not. The documents may come from teaching and research institutions in France or abroad, or from public or private research centers.
L'archive ouverte pluridisciplinaire HAL, est destinée au dépôt et à la diffusion de documents scientifiques de niveau recherche, publiés ou non, émanant des établissements d'enseignement et de recherche français ou étrangers, des laboratoires publics ou privés. 


\section{Histopathology}

Myxoid epithelioid sarcoma: a diagnostic challenge! A report on six cases

\begin{tabular}{|r|l|}
\hline Journal: & Histopathology \\
\hline Manuscript ID: & HISTOP-09-09-0502.R1 \\
\hline Manuscript Type: & Original Article \\
\hline Date Submitted by the & $24-F e b-2010$ \\
\hline Author: & $\begin{array}{l}\text { Flucke, Uta; Radboud University Nijmegen Medical Centre, } \\
\text { Department of Pathology } \\
\text { Hulsebos, Theo; Academic Medical Center, Department of } \\
\text { Neurogenetics } \\
\text { van Krieken, Han; Radboud University Nijmegen Medical Centre, } \\
\text { Department of Pathology } \\
\text { mentzel, thomas; Dermatopathology }\end{array}$ \\
\hline Keywords: & \begin{tabular}{l} 
epithelioid sarcoma, myxoid, soft tissue tumors, myoepithelioma \\
\hline
\end{tabular} \\
\hline
\end{tabular}

\section{S) ScholarONE}

Manuscript Central 


\section{Myxoid epithelioid sarcoma: a diagnostic challenge! A report on six cases}

Uta Flucke, ${ }^{1}$ Theo J M Hulsebos, ${ }^{2}$ J Han J M van Krieken ${ }^{1} \&$ Thomas Mentzel ${ }^{3}$

${ }^{1}$ Department of Pathology, Radboud University Nijmegen Medical Centre, Nijmegen, ${ }^{2}$ Department of Neurogenetics, Academic Medical Center, Amsterdam, The Netherlands, ${ }^{3}$ Dermatopathologie Bodensee, Friedrichshafen, Germany

Short running title: Myxoid epithelioid sarcoma

Key words: epithelioid sarcoma, myxoid, soft tissue tumours, myoepithelioma

Address for correspondence:

U. Flucke

Radboud University Nijmegen Medical Centre

Department of Pathology

P.O. Box 9101

6500 HB Nijmegen

The Netherlands

Fax: +31243668750

Tel: +31243614387

e-mail: u.flucke@pathol.umcn.nl 
Flucke U, Hulsebos T J M, van Krieken J H J M \& Mentzel T

\section{Myxoid epithelioid sarcoma: a diagnostic challenge! A report on six cases}

Aims: Epithelioid sarcoma (ES) is a distinct sarcoma-type with a specific morphology and immunophenotype. Whereas focal myxoid change does occur, to our knowledge only two cases of ES with diffuse myxoid stroma were reported until today. To better characterize the myxoid variant of ES, we describe six additional cases and discuss the differential diagnoses.

Methods and results: Cases were retrieved from the authors' files and studied histologically, immunohistochemically and by molecular methods. The age of the patients, four females and two males, ranged from 16 to 74 years (median: 33 years). The neoplasms arose in an extremity (two cases), the abdominal wall, groin, perineum, and shoulder (one case each). Histologically, four cases were of the conventional type, and two were of the proximal variant and the immunophenotype was typical for ES. The tumour stroma however, revealed prominent myxoid changes, ranging from 50 to 90\% (median: 75\%). Only one of the proximal type ES showed a SMARCB1 mutation, whereas the other tumours had no mutation of this gene.

Conclusions: The myxoid variant of ES represents a diagnostic challenge and may be confused with other myxoid benign and malignant neoplasms. The main differential diagnosis is myoepithelioma of the skin and soft tissue.

Abbreviations: ES, epithelioid sarcoma; EMC, extraskeletal myxoid chondrosarcoma; CK, pancytokeratin; EMA, epithelial membrane antigen; SMA, alpha smooth muscle actin; EMA, epithelial membrane antigen; GFAP, glial fibrillary acidic protein; NA, not analyzed 


\section{Introduction:}

In the first description of 62 cases of epithelioid sarcoma (ES) in 1970 by Enzinger, extensive extracellular mucinous material was present in 5 of 15 cases, that had been stained for mucopolysaccharides. ${ }^{1}$ Nevertheless, myxoid stromal change in ES was described as a rare occurrence in subsequent studies. ${ }^{2-4}$

In contrast to ES, benign or malignant myoepithelial neoplasms of skin and soft tissues show often, at least focally, prominent myxoid stroma.$^{5-9}$ Like ES, cases of myoepithelioma tend to occur on the extremities of adolescents and adults and may show overlapping morphological features with ES such as a nodular proliferation of spindled and epithelioid tumour cells. More rarely, myoepithelioma and ES may occur in children. ${ }^{1,7-11}$ The immunophenotype of myoepitheliomas and ES shares similarities with simultaneous expression of epithelial markers and vimentin, although actins are more rarely expressed in ES. Discriminating markers for myoepitheliomas are S-100, GFAP and calponin, positive in the majority of cases. ${ }^{6-9}$ Approximately 50 to $67 \%$ of ES are positive for CD34 which is not seen in myoepitheliomas. ${ }^{3,5-9,12-16}$ Most cases of ES (> 80\%) show loss of SMARCB1 protein expression, and this phenomenon is also described in a subset of myoepithelial carcinomas. ${ }^{9,16-18}$

In this study we describe the so far largest series of 6 cases of the myxoid variant of the distal and proximal type ES, and discuss the differential diagnosis, with special emphasis on the distinction from benign and malignant myoepithelioma of skin and soft tissue.

\section{Material and methods:}

The cases were retrieved from the files of the Department of Pathology, Radboud University Medical Centre Nijmegen (Nijmegen, The Netherlands), of the Dermatopathologie Bodensee (Friedrichshafen, Germany) and from the consultation files of one of the authors (TM). One case was selected from PALGA, the nationwide network and registry of histopathology and cytopathology in the Netherlands. Slides were reviewed and the diagnosis of ES was based on histological and immunohistochemical criteria according to WHO classification. ${ }^{22}$ Cases in which $50 \%$ or more of the tumour area showed myxoid change were included in the study. The specimens had been obtained by surgical excision, fixed in $10 \%$ buffered formalin, and processed for paraffin embedding. Four micrometer-thick sections were stained with haematoxylin and eosin, and immunohistochemically by the labeled streptavidinbiotin technique using commercially available antibodies; appropriate positive and negative controls were used in each case. Antibodies, their sources and dilutions are summarized in Table 1. 
Genomic DNA was extracted from the paraffin embedded specimens of all six cases by use of commercially available kits (Qiagen, Venlo, The Netherlands). SMARCB1 mutation analysis was performed as described previously. ${ }^{23}$

The clinical information were obtained from the referring clinicians and pathologists.

\section{Results:}

\section{Clinical findings}

Details are summarized in Table 2.

The neoplasms arose in four females and two males. The age of the patients ranged from 16 to 74 years (median: 33 years). Anatomic sites included the extremities (two cases), the abdominal wall, perineum, groin, shoulder (one case each). The patients were treated by wide excision or reexcision with tumour free margins in all cases. Local recurrences were seen in three cases, two of the distal and one of the proximal type. The two recurring neoplasm of the distal type showed two and four recurrences respectively and subsequently lymph node metastases developed.

\section{Pathological features}

The size of the neoplasms ranged from 1.0 to $4.0 \mathrm{~cm}$ (median: $1.8 \mathrm{~cm}$ ). Sites of involvement were the dermis and subcutis of the abdominal wall, schoulder, and, hand and soft tissue of the lower leg (distal type), and subcutis of the groin, and vulva ( proximal type).

Microscopically, in all tumours a (multi)nodular growth with infiltrative margins was seen (Figure 1). The tumour cells were arranged in nests and cords, with the myxoid stromal background. A reticular growth pattern was observed in three cases (two of the distal type and one of the proximal type)

(Figures 2 and 3). Classical solid areas were seen in all cases (Figures 1 and 4). The epithelioid tumour cells contained abundant eosinophilic cytoplasm and round, vesicular nuclei. Prominent nucleoli were variably seen. In all four cases of the distal type scattered spindle-shaped tumour cells were noted. In two cases plasmocytoid cells were also recognized (Figure 5). Centrally the tumours showed hyalinization ( 4 cases) and/or necrosis ( 3 cases).

The two cases of proximal type were composed of larger epithelioid and rhabdoid tumor cells (Figures 3 and 4).

Necrosis was seen in one of the proximal type, and in all but one of the distal ES. Inflammatory reaction was more prominent in the cases of the distal type. The mitotic rate ranged from 12 to 24 mitoses per $2 \mathrm{~mm}^{2}$ in the cases of the proximal type and from 3 to 11 mitoses per $2 \mathrm{~mm}^{2}$ in the cases of the distal type. 
Two cases were $90 \%$ myxoid, and one case each showed $80 \%$ and $70 \%$ myxoid stromal change, whereas in two cases 50\% myxoid areas were observed (Table 2).

Immunohistochemically, tumour cells in all cases stained strongly positive for vimentin, pancytokeratin (Figure 6) and EMA. In addition, CD34 was positive in two cases (Figure 7), and expression of SMA was focally present in two cases. A weak and focal positivity of calponin was seen in three cases. SMARCB1 (BAF47) was absent in all six cases (Figure 8). None of the neoplasms expressed S-100 protein, GFAP, and p63 (Table 3).

\section{SMARCB1 gene status}

All tumours were investigated for the presence of mutations in the SMARCBI gene. In one of them a mutation in exon 6 was recognized, which we reported previously. ${ }^{20}$ In this case of proximal type, localized in the vulva, we identified a c.769C $>\mathrm{T}$ transition resulting in the generation of an in-frame stopcodon (CAG->TAG, p.Q257X) in the transcript and premature termination of SMARCB1INI1 protein synthesis. In accordance with the two-hit model for tumour genesis, we noted considerable loss of the wild-type copy of this gene in the tumour. All other cases had no mutation of SMARCB1.

\section{Discussion:}

Myxoid tumours of soft tissue encompass a heterogenous group of lesions characterized by a marked abundance of extracellular mucoid (myxoid) matrix. They demonstrate significant variability in their biological behavior thus including indolent tumours, tumours with a tendency to recur locally but not metastasize, and malignant tumours. ${ }^{24}$

Although prominent myxoid stromal changes in classical ES is well known, to date, to our knowledge only two cases of ES with diffuse myxoid changes have been described. ${ }^{1,4,14,25}$

We report an additional series of six cases of myxoid ES and discuss their morphological, immunohistochemical and molecular features, and the differential diagnosis to other benign and malignant neoplasms of skin and soft tissues.

The reported neoplasms, two of the proximal and four of the distal type, were localized in the dermis, subcutis and deep soft tissues, and showed classical morphological and immunohistochemical features of ES as established. In addition, prominent myxoid stromal changes were seen in all cases, and tumour cells were often arranged in cords and nests, a rather reticular architecture was seen in three cases.

Our findings are comparable to those described earlier for two distal type myxoid ES. ${ }^{25}$ 
All cases were negative for SMARCB1 protein expression. This confirms recently published studies, showing loss of SMARCB1 protein expression in more than $80 \%$ of cases of ES. ${ }^{16-18,20}$ Only one of our proximal type ES showed a SMARCB1 mutation, whereas the other tumours had no mutation. The low frequency of mutations affecting the SMARCBI gene in our series of ES is comparable to others and suggests that the expression of SMARCB1 in this tumour type is down-regulated by alternative mechanisms, such as epigenetic modification. ${ }^{18,20}$

The main differential diagnosis of myxoid ES represents myoepithelioma of skin and soft tissues. These neoplasms also arise predominantly in the extremities of (young) adults and children. Because of the plasticity of myoepithelial cells, they show heterogeneous morphological features, consisting of spindled, epithelioid, plasmocytoid and clear cells often set in a (chondro)myxoid or collagenous/hyalinized stroma. ${ }^{5-8}$ Hence there is morphological overlap with myxoid ES, showing predominantly epithelioid and spindle shaped cells. Ductal structures in myoepitheliomas are of help in the distinction of both entities. This feature was not observed in our cases. Futhermore all of our cases showed also classical morphology of ES in at least $10 \%$ of tumour area. The distal variants in our series had a granulomatous appearance and necrosis. Moreover none of the tumours of our series expressed S-100 protein, which was seen in $87 \%$ respective $93 \%$ of myoepithelial neoplasms. ${ }^{7,8}$ The presence of pankeratin and EMA was $100 \%$ in our cases as expected in ES, while AE1/AE3 was positive in only $77 \%$ and EMA only in $63 \%$ of myoepithelial neoplasms. ${ }^{7}$ Smaller series showed similar results. ${ }^{8,9}$ The focal staining for SMA in two and calponin among three of our cases was very weak and incomparable to what is seen in myoepithelial neoplasms. ${ }^{5-9}$ Two of our cases showed discriminating positivity for CD34, which is in line with approximately $50 \%$ of ES. ${ }^{3,13,14,16}$ Negative staining results we observed for GFAP, and p63, analogous to the results of others, whereas positivity was described in myoepithelial neoplasms in about $46-100 \%$ and $7-27 \%$ respectively. ${ }^{6-9,15}$

Like in ES, SMARCB1 protein expression in myoepithelial carcinomas may be absent, as it has been shown recently. ${ }^{9,17}$ The genetic background thereof is still unknown.

Epithelioid haemangioendothelioma (EHE) of skin and soft tissues may also enter the differential diagnosis of myxoid ES. This distinct malignant vascular tumour, most commonly occurring in middle-aged patients, has a wide range of localization. Tumours of the skin are very rare and described as both single and multiple lesions; the last is typically in progressive ES. Histologically, EHE shows a (multi)nodular architecture and is composed of short strands, cords, or small clusters of epithelioid to slightly spindled cells with an eosinophil cytoplasm and vesicular nuclei. Intracytoplasmatic vacuoles, usually a prominent feature in EHE, could be in some cases very subtle and are occasionally recognized in ES due to lipid droplets. The typically myxohyaline stroma shows variably haemorrhage and/or haemosiderin deposits. Discriminating immunohistochemical features are positivity for specific 
endothelial markers, as CD31 (with a strong membranous reaction) and Fli-1 (with nuclear staining) in EHE, whereas EMA, usually positive in ES, was rarely focally detected in EHE. Cytokeratin and CD34, variably positive in both tumours, are not useful in the differential diagnosis. ${ }^{26-29}$

Another differential diagnosis of ES represents extraskeletal myxoid chondrosarcoma (EMC). EMC typically shows a multinodular growth pattern with interlacing cords of round or plump spindled tumour cells set in a chondomyxoid background. In contrast to ES, the cells of EMC are less epithelioid and the architecture is more homogeneous. A cellular high grade variant and rhabdoid features is also described showing greater degree of morphological overlap especially with proximal type ES. ${ }^{30,31}$ The rhabdoid features in EMC were associated with loss of SMARCB1/INI1 expression and partly with genetic alteration in SMARCBI/INI. ${ }^{31}$ If requiring immunohistochemistry for a definitive diagnosis, S-100 is expressed in a minority of cases, and epithelial and myogenic markers are usually absent. ${ }^{7,32}$ Typical translocations, $\mathrm{t}(9 ; 22)$ (q22;q12), t(9;17) (q22;q11), and t(9;15) (q22;q21), furnish proof of this sarcoma. ${ }^{33,34}$

Recently an epithelioid variant of myxofibrosarcoma has been described composed of mainly epithelioid fibroblastic cells set in a myxoid stroma. In addition pseudolipoblasts and numerous elongated, curvilinear blood vessels are present, mostly seen in the hypocellular myxoid areas. ${ }^{35}$ This tumour usually arises in elderly patients, lacks the expression of epithelial markers and do not show loss of SMARCB1 protein expression.

In summary myxoid ES represents a rare variant in the spectrum of ES and prominent myxoid stromal changes are seen in the distal and proximal type respectively. Particularly in small biopsies correct diagnosis can be problematic, and cases of benign and malignant myoepithelioma, extraskeletal myxoid chondrosarcoma and epithelioid myxofibrosarcoma have to be distinguished from myxoid ES. 


\section{References:}

1. Enzinger FM. Epithelioid sarcoma: a sarcoma simulating a granuloma or a carcinoma. Cancer 1970; 26; 1029-1041.

2. Evans HL, Baer SC. Epithelioid sarcoma: a clinicopathologic and prognostic study of 26 cases. Semin. Diagn. Pathol. 1993; 10; 286-291.

3. Hasegawa T, Matsuno Y, Shimoda T, Umeda T, Yokoyama R, Hirohashi S. Proximal-type epithelioid sarcoma: a clinicopathologic study of 20 cases. Mod. Pathol. 2001; 14; 655663.

4. Fisher C. Epithelioid sarcoma of Enzinger. Adv. Anat. Pathol. 2006; 13; 114-121.

5. Kilpatrick SE, Hitchcock MG, Kraus MD, Calonje E, Fletcher CDM. Mixed tumors and myoepitheliomas of soft tissue: A clinicopathologic study of 19 cases with a unifying concept. Am. J. Surg. Pathol. 1997; 21; 13-22.

6. Kutzner H, Mentzel T, Kaddu S, Soares LM, Sangueza OP, Requena L. Cutaneous myoepithelioma: an underecognized cutaneous neoplasm composed of myoepithelial cells. Am. J. Surg. Pathol. 2001; 25; 348-355.

7. Hornick JL, Fletcher CDM. Myoepithelial tumors of soft tissue. A clinicopathologic and immunohistochemical study of 101 cases with evaluation of prognostic parameters. Am. $J$. Surg. Pathol. 2003; 27; 1183-1196.

8. Hornick JL, Fletcher CDM. Cutaneous myoepithelioma: A clinicopathologic and immunohistochemical study of 14 cases. Hum. Pathol. 2004; 35; 14-24.

9. Gleason BC, Fletcher CDM. Myoepithelial carcinoma of soft tissue in children: An aggressive neoplasm analysed in a series of 29 cases. Am. J. Surg. Pathol. 2007; 31; $1813-$ 1824.

10. Chase DR, Enzinger FM. Epithelioid sarcoma: Diagnosis, prognostic indicators and treatment. Am. J. Surg. Pathol. 1985; 9; 241-263.

11. Casanova M, Ferrari A, Collini P et al. Epithelioid sarcoma in children and adolescents: A report from the Italian Soft Tissue Sarcoma Committee. Cancer 2006; 106; 708-717.

12. Mirra JM, Kessler S, Butha S, Eckhardt J. The fibroma-like variant of epithelioid sarcoma. Cancer 1992; 69; 1382-1395.

13. Guillou L, Wadden C, Coindre JM, Krausz T, Fletcher CDM. Proximal-type epithelioid sarcoma, a distinctive aggressive neoplasm showing rhabdoid features: clinicopathologic, immunohistochemical, and ultrastructural study of a series. Am. J. Surg. Pathol. 1997; 21; 130-146.

14. Miettinen M, Fanburg-Smith JC, Virolainen M, Shmookler BM, Fetch JF. Epithelioid sarcoma: an immunohistochemical analysis of 112 classical and variant cases and a discussion of the differential diagnosis. Hum. Pathol. 1999; 30; 934-942. 
15. Laskin WB, Miettinen M. Epithelioid sarcoma. New insights based on an extended immunohistochemical analysis. Arch. Pathol. Lab. Med. 2003; 127; 1161-1168.

16. Chbani L, Guillou L, Terrier P et al. Epithelioid sarcoma. A clinicopathologic and immunohistochemical analysys of 106 cases from the French Sarcoma Group. Am. J. Clin. Pathol. 2009; 13; 222-227.

17. Hornick JL, Dal Cin P, Fletcher CDM. Loss of INI1 expression is characteristic of both conventional and proximal-type epithelioid sarcoma. Am. J. Surg. Pathol. 2009; 33; 542550.

18. Kohashi K, Izumi T, Oda Y, et al. Infrequent SMARCB1/INI1 gene alteration in epithelioid sarcoma: a useful tool in distinguishing epithelioid sarcoma from malignant rhabdoid tumor. Hum. Pathol. 2009; 40; 349-355.

19. Modena P, Lualdi E, Facchinetti F, et al. SMARB1/INI1 tumor suppressor gene is frequently inactivated in epithelioid sarcomas. Cancer Res. 2005; 65; 4012-4019.

20. Flucke U, Mentzel T, Slootweg PJ, Pauwels P, Hulsebos TJM. Direct evidence of mutational inactivation of SMARCBI/INI1 in epithelioid sarcoma. Hum. Pathol. 2009; 40; 1361-1362.

21. von Hochstetter AR, Meyer VE, Grant JW, Honegger HP, Schreiber A. Epithelioid sarcoma mimicking angiosarcoma: the value of immunohistochemistry in the differential diagnosis. Virchows Arch. A Pathol. Anat. Histopathol. 1991; 418; 271-278.

22. Guillou L, Kaneko Y. Epithelioid sarcoma. In Fletcher CDM, Unni KK and Mertens F eds. Pathology and Genetics of Tumours of Soft Tissue and Bone. World Health Organisation Classification of Tumours. Lyon, France: IARC Press; 2002; 205-207.

23. Hulsebos TJM, Plomp AS, Wolterman RA, Robanus-Maandag EC, Baas F, Wesseling P. Germline mutation of INII/SMARCBI in familial schwannomatosis. Am. J. Hum. Gen. 2007; 80; 805-810.

24. Graadt van Roggen JF, Hogendoorn PCW, Fletcher CDM. Myxoid tumors of soft tissue. Histopathology 1999; 35; 291-312.

25. Fadare O. Myxoid epithelioid sarcoma: Clinicopathologic analysis of 2 cases. Int. J. Surg. Pathol. 2009; 17; 147-152.

26. Quante M, Patel NK, Hill S, et al. Epithelioid hemangioendothelioma presenting in the skin : A clinicopatholologic study of eight cases. Am. J. Dermatopathol. 1998; 20; 541546.

27. Weiss SW, Ishak KG, Dail DH, Sweet DE, Enzinger FM. Epithelioid hemangioendothelioma and related lesions. Semin. Diagn. Pathol. 1986; 3; 259-287.

28. Mentzel T, Beham A, Calonje E, Katenkamp D, Fletcher CDM. Epithelioid hemangioendothelioma of skin and soft tissues : clinicopathologic and imuunohistochemical study of 30 cases. Am. J. Surg. Pathol. 1997; 21; 363-374. 
29. Billings SD, Folpe AL, Weiss SW. Epithelioid sarcoma like hemangioendothelioma. Am. J. Surg. Pathol. 2003; 27; 48-57.

30. Lucas DR, Fletcher CDM, Adsay NV, Zalupski MM. High-grade extraskeletal myxoid chondrosarcoma: a high-grade epithelioid malignancy. Histopathology 1999; 35; 201-208.

31. Kohashi K, Oda Y, Yamamoto H et al. SMARCB1/INI1 protein expression in round cell soft tissue sarcomas associated with chromosomal translocations involving EWS: A special reference to SMARCB1/INI1 negative variant extraskeletal myxoid chondrsarcoma. Am. J. Surg. Pathol. 2008; 32; 1168-1174.

32. Oliveira AM, Sebo TJ, McGrory JE, Gaffey TA, Rock MG, Nascimento AG. Extraskeletal myxoid chondrosarcoma: a clinicopathologic, immunohistochemical, and ploidy analysis of 23 cases. Mod. Pathol. 2000; 13; 900-908.

33. Sciot R, Dal Cin P, Fletcher C, et al. T(9;22) (q22-31;q11-12) is a consistent marker of extraskeletal myxoid chondrsarcoma: evaluation of three cases. Mod. Pathol. 1995; 8; 765768.

34. Hisaoka M, Ishida T, Imamura T, Hashimoto H. TFG is a novel fusion partner of NOR1 in extraskeletal myxoid chondrosarcoma. Genes Chromosomes Cancer 2004; 40; 325-328.

35. Nascimento AF, Bertoni F, Fletcher CDM. Epithelioid variant of myxofbrosarcoma: expanding the clinicomorphologic spectrum of myxofibrosarcoma in a series of 17 cases. Am. J. Surg. Pathol. 2007; 31; 99-105. 
Acknowledgement:

The authors thank PALGA, the nationwide network and registry of histopathology and cytopathology in the Netherlands, especially Dr. Mariel Casparie, for selecting epithelioid sarcoma cases. 
Figure 1. Classical features in one of the distal type ES (case 1) with nodular architecture and inflammatory reaction; myxoid background is also seen.

Figure 2. Epithelioid and spindle-shaped tumour cells in case 3 are arranged in cords given a reticular growth pattern. Note the prominent myxoid stroma.

Figure 3. This neoplasm of the proximal type is composed of nests and cords of enlarged tumour cells with rhabdoid features (case 2).

Figure 4. Predominantly solid areas in a proximal type ES (case 6).

Figure 5. Epithelioid and spindle tumour cells set in a prominent myxoid stroma; scattered plasmocytoid cells are also present (case 4).

Figure 6. Pan-cytokeratin expression was a characteristic feature of all cases (case 6).

Figure 7. CD34 positivity was observed in two cases (case 6).

Figure 8. All cases showed loss of SMARCB1 protein expression (case 6). 
Table 1. Panel of antibodies used in this study

$\begin{array}{llll}\text { Antigen } & \text { Clone } & \text { Dilution } & \text { Source } \\ \text { Vimentin } & \text { V9 } & 1: 150 & \text { Dako } \\ \text { Pan-cytokeratin } & \text { MNF116 } & 1: 100 & \text { Dako } \\ \text { Pan-cytokeratin } & \text { AE1/3 } & 1: 50 & \text { Dako } \\ \text { CD34 } & \text { HPCA-1 } & 1: 100 & \text { Becton \& Dickinson } \\ \text { SMA } & 1 \text { A4 } & 1: 300 & \text { Dako } \\ \text { BAF 47 } & 25 & 1: 250 & \text { BD Transduction Laboratories } \\ \text { S-100 } & \text { Polyclonal } & 1: 2000 & \text { Dako } \\ \text { Calponin } & \text { CALP1 } & 1: 400 & \text { Dako } \\ \text { EMA } & \text { E29 } & 1: 3000 & \text { Dako } \\ \text { P63 } & \text { 4A4 } & 1: 400 & \text { Dako } \\ \text { GFAP } & \text { GA-5 } & 1: 200 & \text { Biogenix }\end{array}$


Table 2. Clinical and morphological details of six cases of myxoid ES

\begin{tabular}{|c|c|c|c|c|c|c|c|c|}
\hline Case & Sex & $\begin{array}{l}\text { Age } \\
\text { (years) }\end{array}$ & Location & Type & $\begin{array}{l}\text { Size } \\
(\mathrm{cm})\end{array}$ & $\begin{array}{l}\text { Amount } \\
\text { of } \\
\text { myxoid } \\
\text { changes } \\
(\%)\end{array}$ & $\begin{array}{l}\text { Recurrences } \\
\text { (n) }\end{array}$ & Metastases \\
\hline 1 & $\mathrm{M}$ & 48 & $\begin{array}{l}\text { abdominal } \\
\text { wall } \\
\text { (dermis, } \\
\text { subcutis) }\end{array}$ & distal & 1.6 & 80 & 2 & $\begin{array}{l}\text { lymph } \\
\text { node groin }\end{array}$ \\
\hline 2 & $\mathrm{~F}$ & 22 & $\begin{array}{l}\text { vulva } \\
\text { (subcutis) }\end{array}$ & proximal & 1.5 & 70 & NA & NA \\
\hline 3 & $\mathrm{~F}$ & 16 & $\begin{array}{l}\text { lower leg } \\
\text { (soft } \\
\text { tissue) }\end{array}$ & distal & 2.0 & 90 & NA & $\mathrm{NA}$ \\
\hline 4 & $\mathrm{M}$ & 74 & $\begin{array}{l}\text { shoulder, } \\
\text { (dermis, } \\
\text { subcutis) }\end{array}$ & distal & 4.0 & 50 & no & no \\
\hline 5 & $\mathrm{~F}$ & 41 & $\begin{array}{l}\text { hand } \\
\text { (subcutis) }\end{array}$ & distal & 1.0 & 50 & 4 & $\begin{array}{l}\text { lymph } \\
\text { nodes } \\
\text { axilla }\end{array}$ \\
\hline 6 & $\mathrm{~F}$ & 25 & $\begin{array}{l}\text { groin } \\
\text { (subcutis) }\end{array}$ & proximal & 4.0 & 90 & 1 & NA \\
\hline
\end{tabular}


Table 3. Immunohistochemical results of six cases of myxoid ES

\begin{tabular}{|c|c|c|c|c|c|c|c|c|c|c|}
\hline Case & Vimentin & $\mathrm{CK}$ & CD34 & EMA & SMA & BAF47 & S100 & GFAP & P63 & Calponin \\
\hline 1 & + & + & + & + & - & - & - & - & - & - \\
\hline 2 & + & + & - & + & - & - & - & - & - & - \\
\hline 3 & + & + & - & + & $\begin{array}{l}+ \\
\text { focal }\end{array}$ & - & - & - & - & $\begin{array}{l}+ \\
\text { focal,weak }\end{array}$ \\
\hline 4 & + & + & - & + & - & - & - & - & - & $\begin{array}{l}+ \\
\text { focal,weak }\end{array}$ \\
\hline 5 & + & + & - & + & $\begin{array}{l}+ \\
\text { focal }\end{array}$ & - & - & - & - & $\begin{array}{l}+ \\
\text { focal,weak }\end{array}$ \\
\hline 6 & + & + & + & + & - & - & - & - & - & - \\
\hline
\end{tabular}




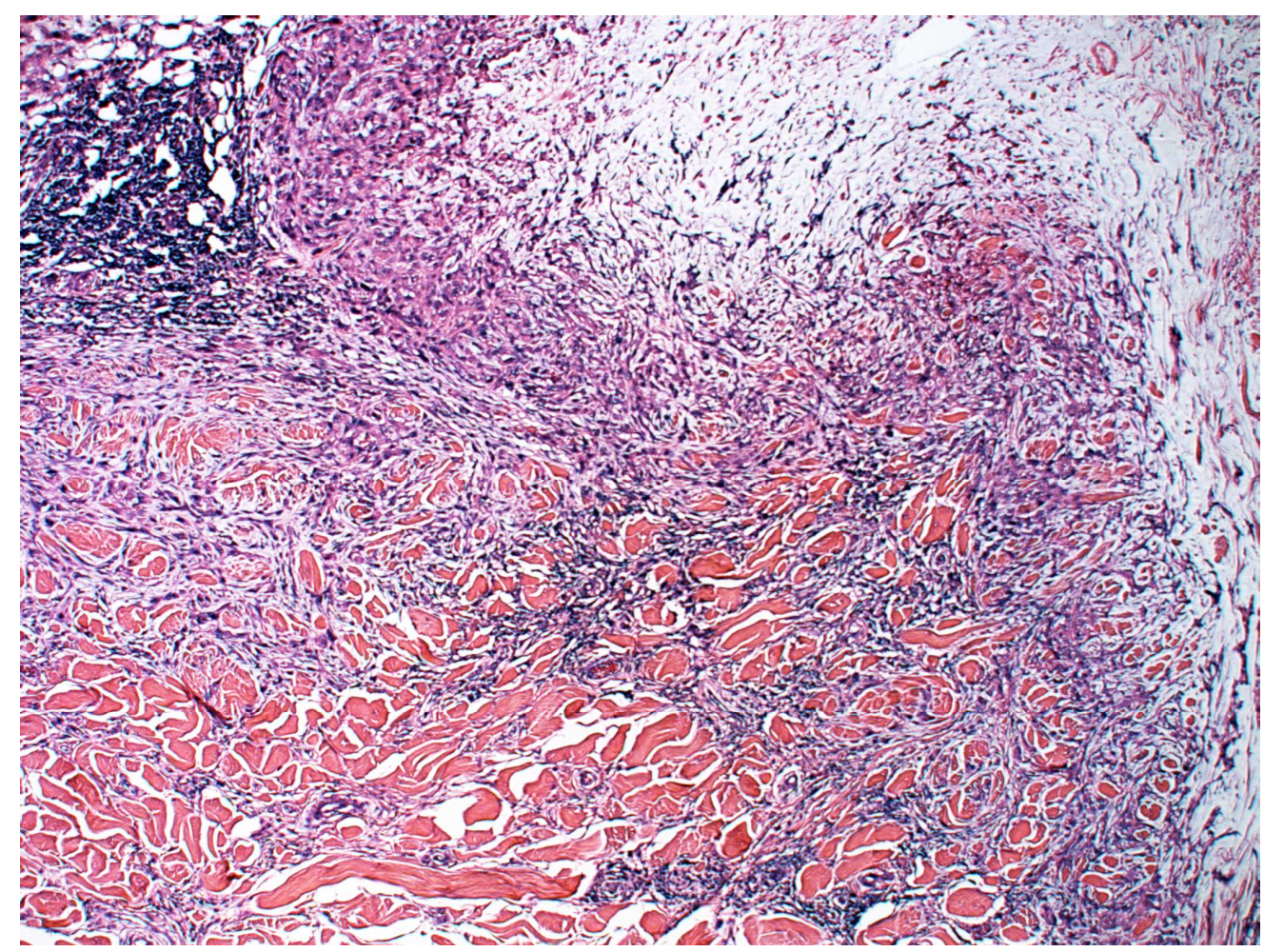

Classical features in one of the distal type ES (case 1) with nodular architecture and inflammatory reaction; myxoid background is also seen $180 \times 134 \mathrm{~mm}(300 \times 300 \mathrm{DPI})$ 


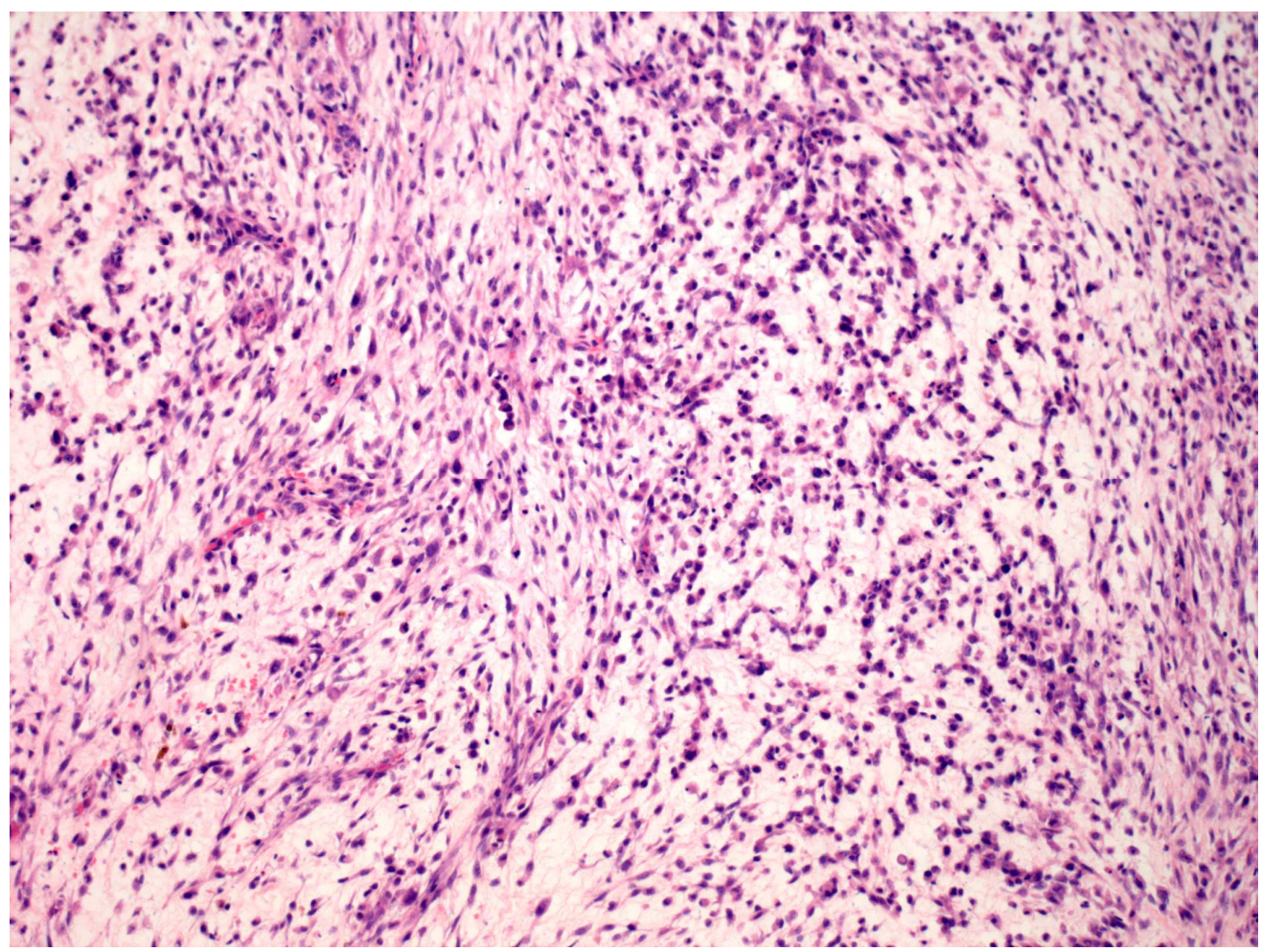

Epithelioid and spindle-shaped tumour cells in case 3 are arranged in cords given a reticular growth pattern. Note the prominent myxoid stroma. $180 \times 134 \mathrm{~mm}(300 \times 300$ DPI $)$ 


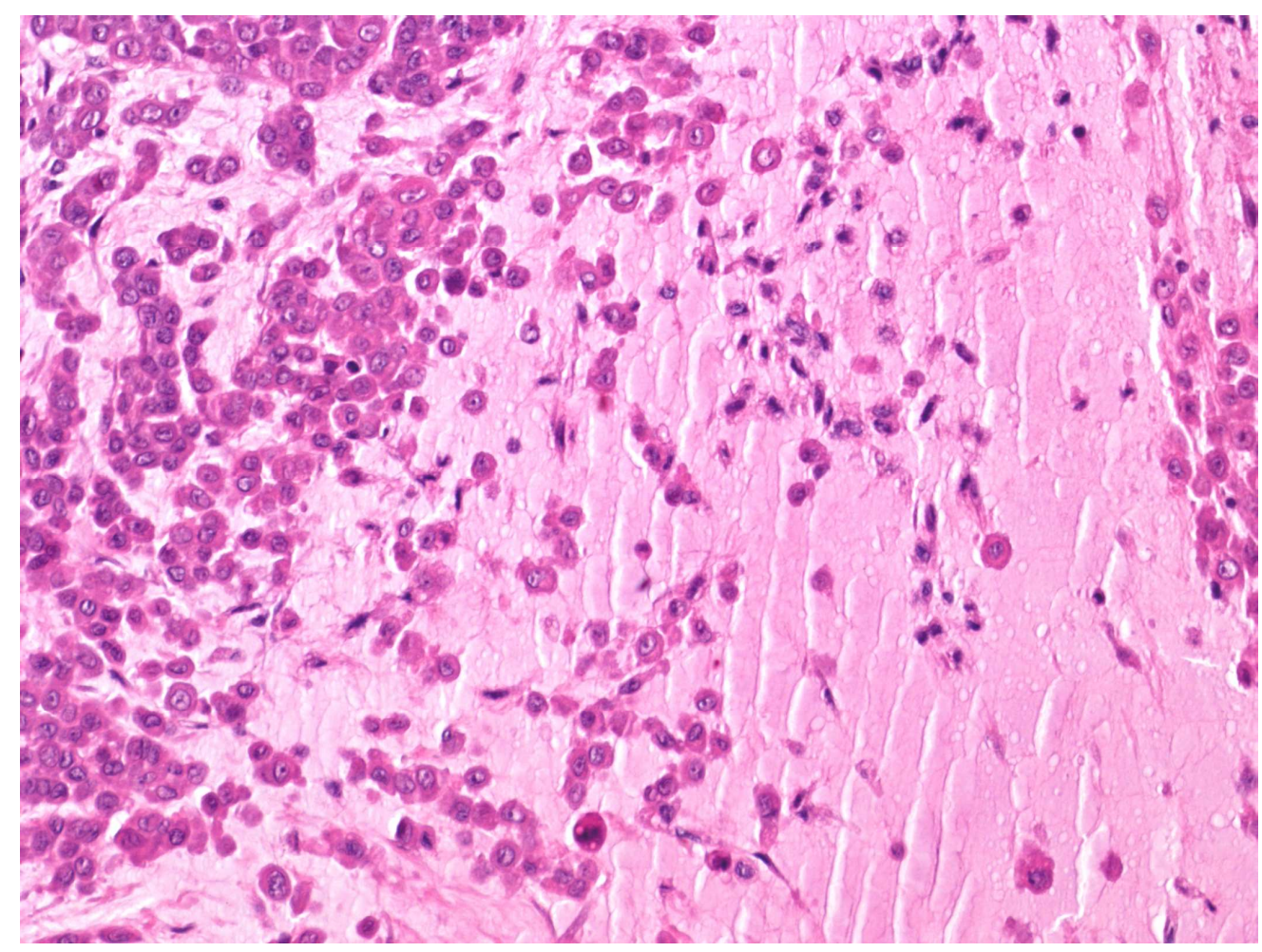

This neoplasm of the proximal type is composed of nests and cords of enlarged tumour cells with rhabdoid features (case 2 ).

$180 \times 134 \mathrm{~mm}(300 \times 300 \mathrm{DPI})$ 


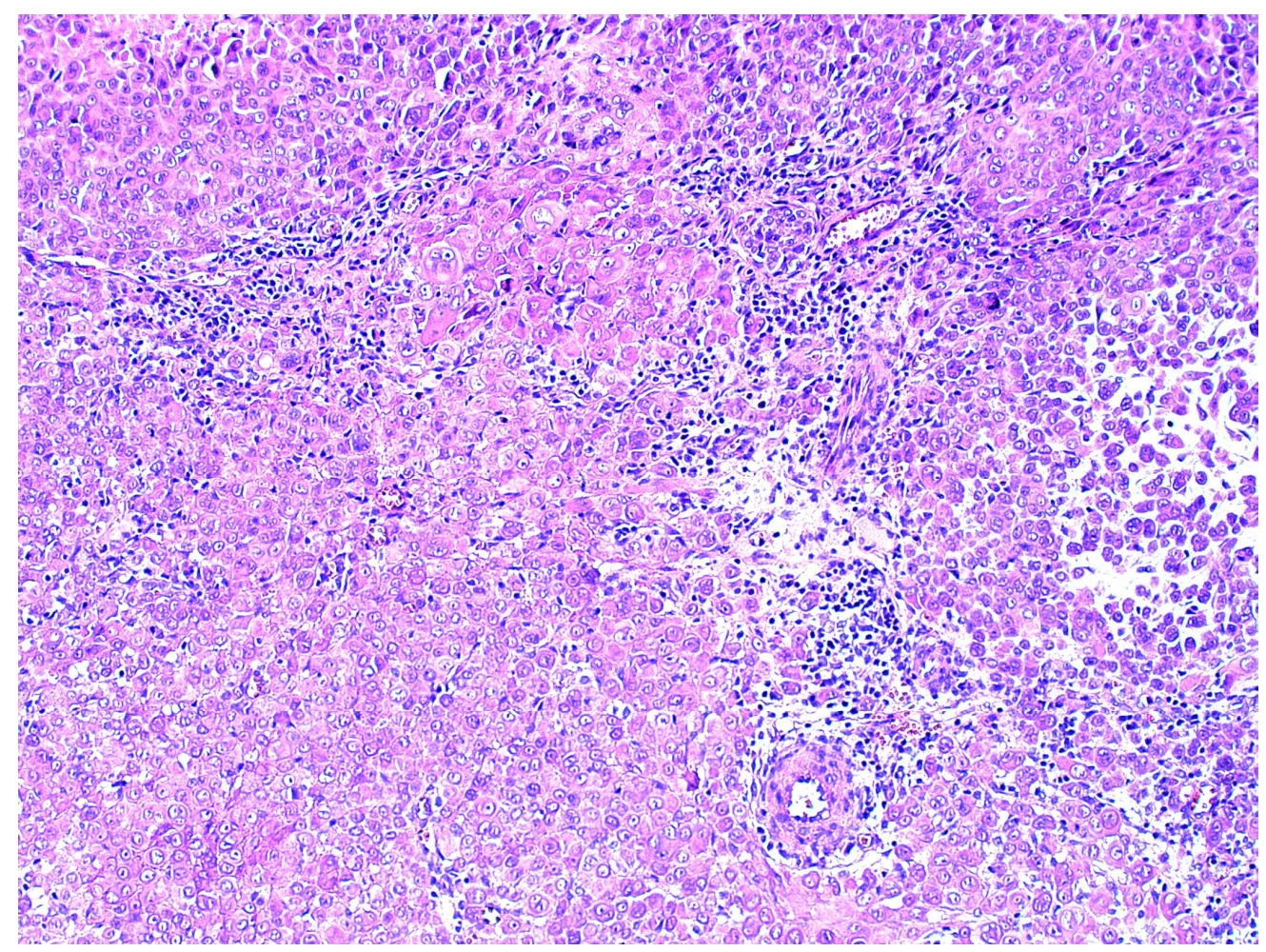

Predominantly solid areas in a proximal type ES (case 6). $180 \times 134 \mathrm{~mm}(300 \times 300 \mathrm{DPI})$ 


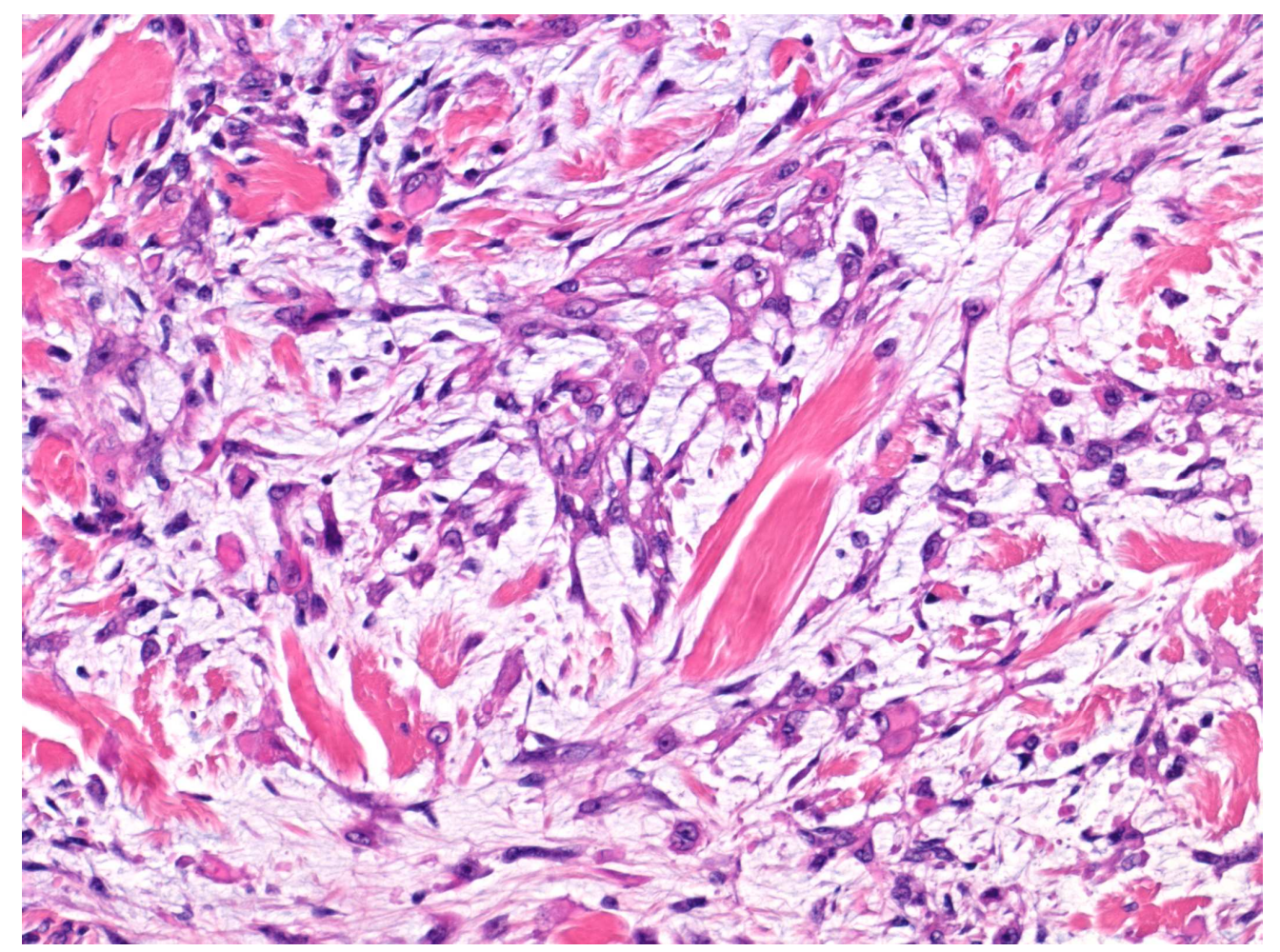

Epithelioid and spindle tumour cells set in a prominent myxoid stroma; scattered plasmocytoid cells are also present (case 4$)$.

$180 \times 134 \mathrm{~mm}(300 \times 300 \mathrm{DPI})$ 


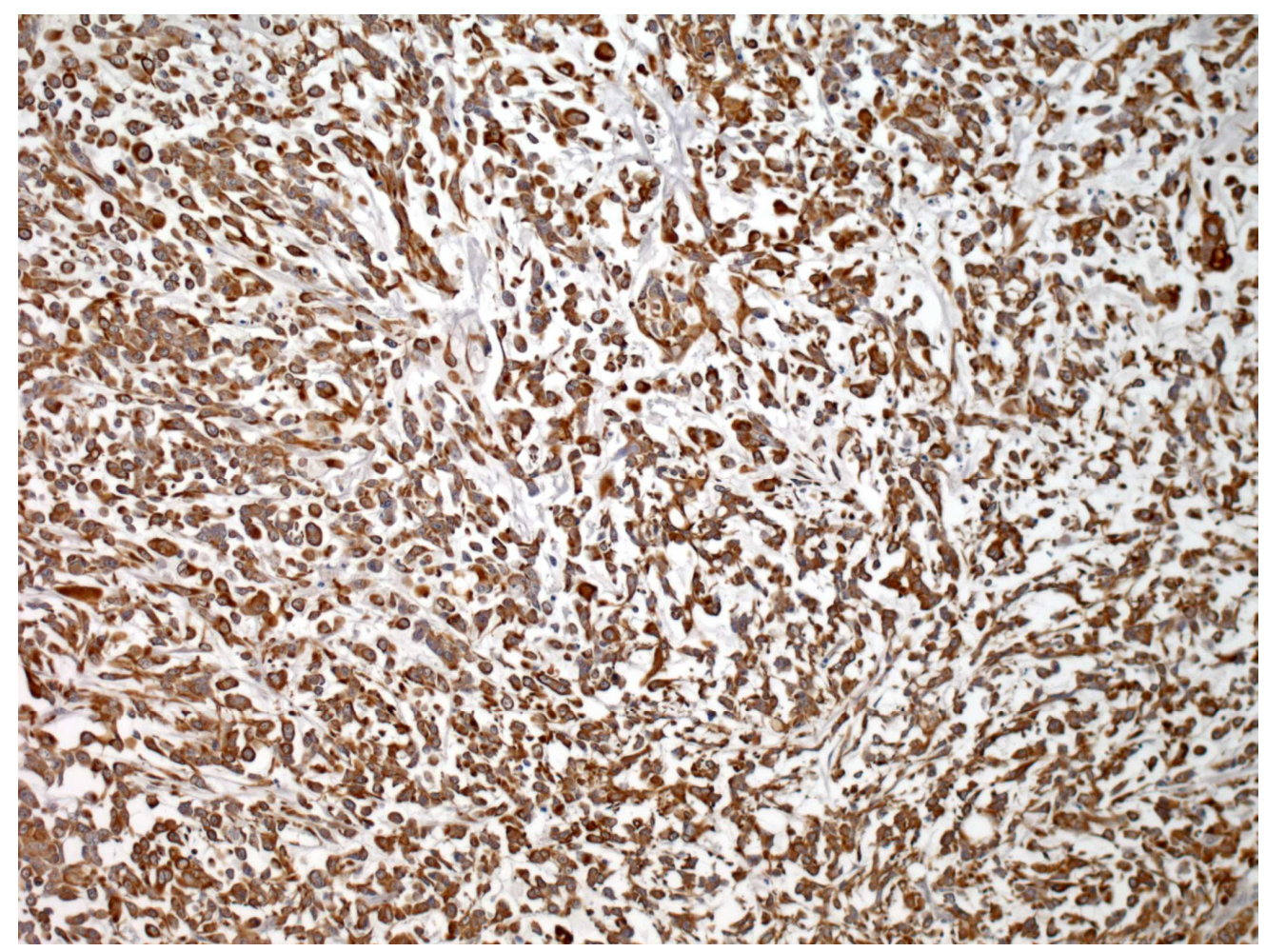

Pan-cytokeratin expression was a characteristic feature of all cases (case 6). $180 \times 134 \mathrm{~mm}(300 \times 300 \mathrm{DPI})$ 


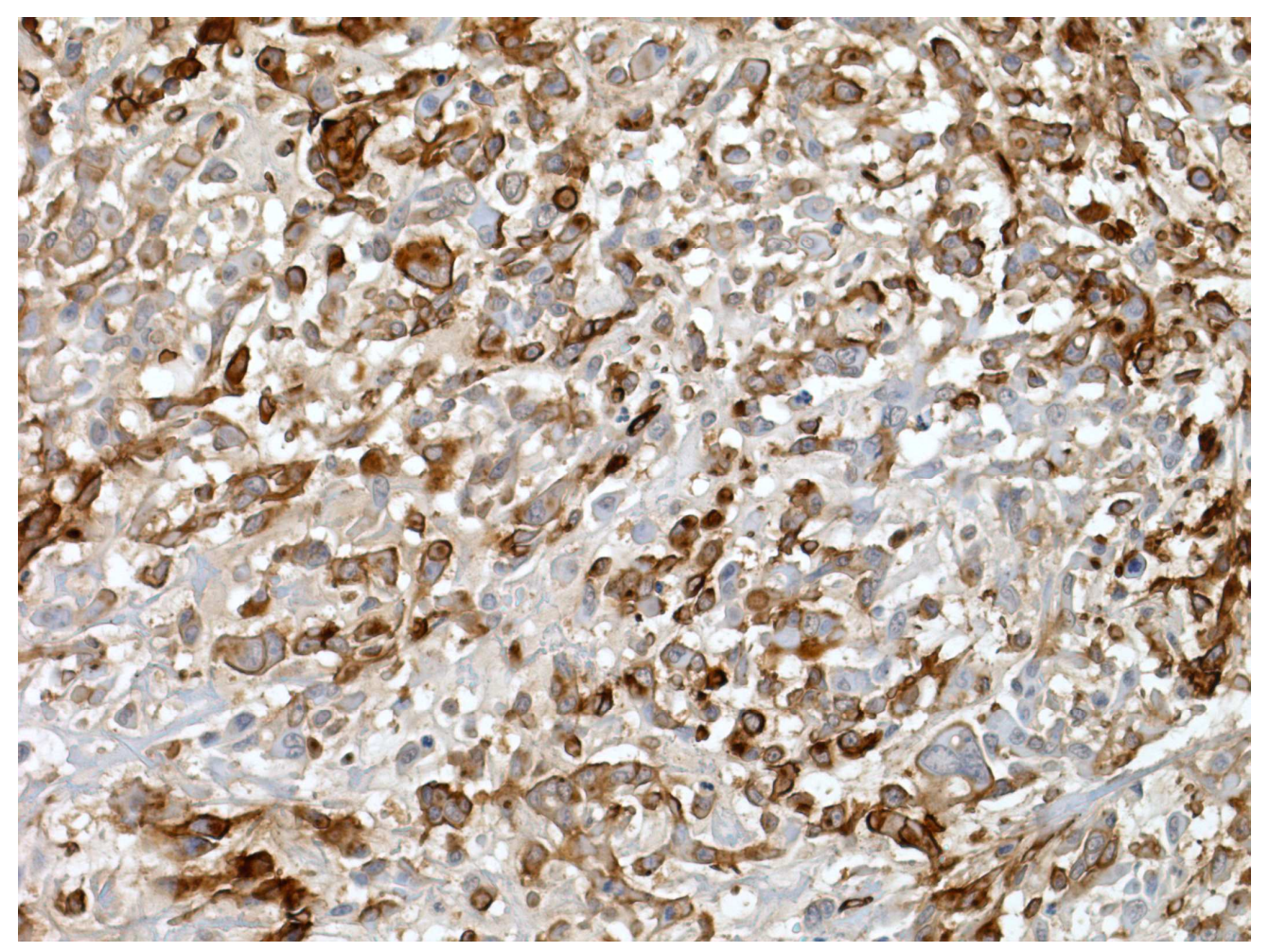

CD34 positivity was observed in two cases (case 6 ). $180 \times 134 \mathrm{~mm}(300 \times 300 \mathrm{DPI})$ 


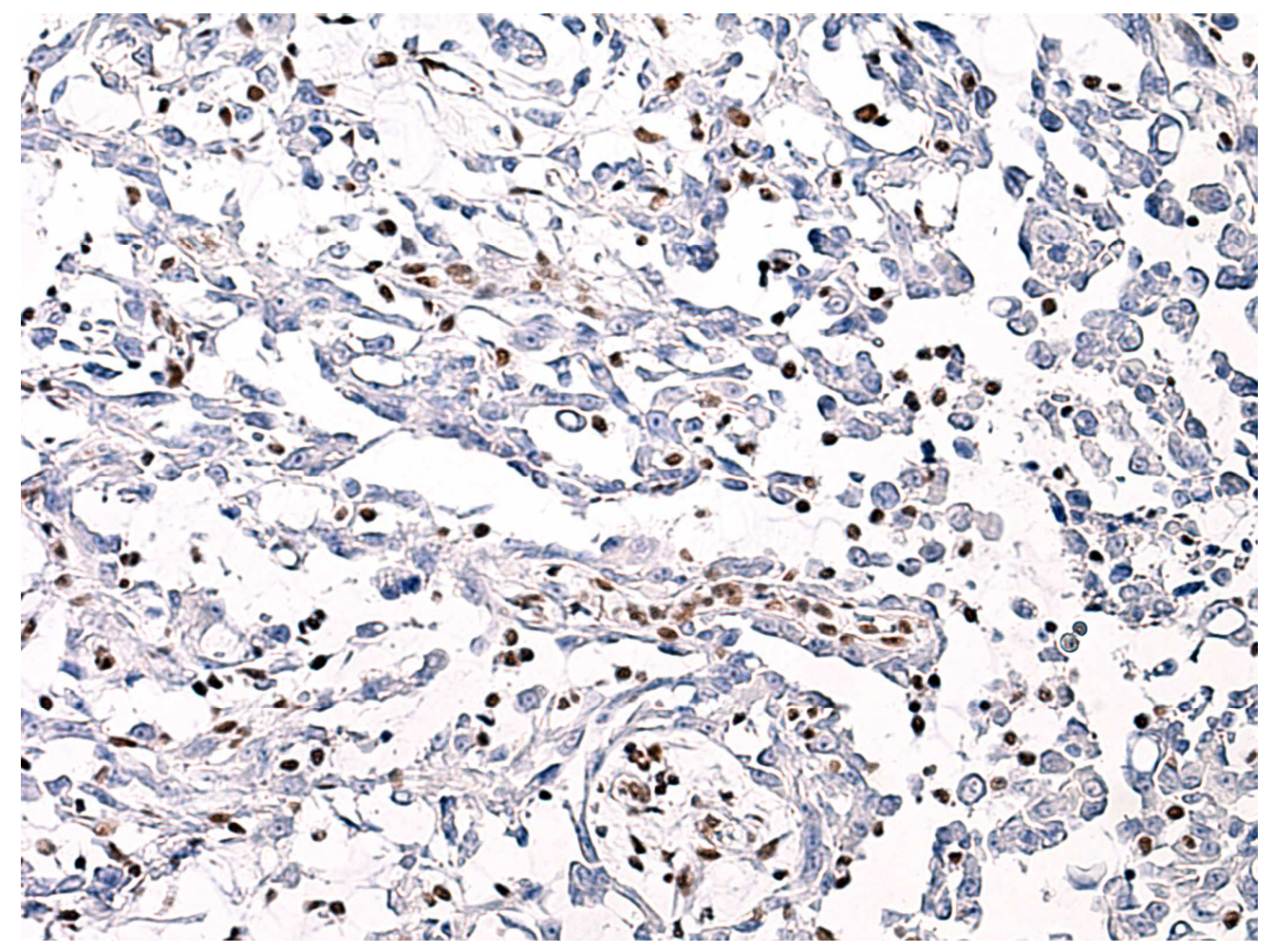

All cases showed loss of SMARCB1 protein expression (case 6). $180 \times 134 \mathrm{~mm}(300 \times 300 \mathrm{DPI})$ 